PART 2

Exordium 
William B. Warner - 9789004362871

Downloaded from Brill.com04/26/2023 01:08:14PM via free access 


\title{
Truth and Trust and the Eighteenth-Century Anglophone Newspaper
}

\author{
William B. Warner
}

Newspapers carry accounts of events that have happened, but which are not yet known to the reader. How did the early readers of the newspaper come to trust these accounts as true? We can open some of the complexity of that question by noting that there are at least five constituents for the news: novelty, mediation, spatial transport, temporal lag, and truthfulness. News draws on two senses of novelty. News is novel because it is newly known. Although it can include the banal, the routine and the everyday, the most compelling news is 'novel' in another sense: rare, surprising and improbable. Secondly, to become news there must be some form of mediation that fixes and records an event, whether as words written or printed upon paper, as a memory in the mind of the messenger, as signals of some kind. Thirdly, news implies spatial transport. Recorded in some form, a told event is transported through space, from the place of its formulation to where it is received. Fourthly, in the era before electronic media, spatial transport entailed a temporal lag between the time of recording and reception. Finally, to become news, the communication must satisfy the recipient's expectation that it is truthful.

I use the word 'truth' advisedly. The truth that one can find in a newspaper account is not the truth of speculative philosophy, where one might ask, with a certain carefully developed scepticism, 'what is Truth?' Instead, newspapers engage a truth that is more prosaic, close to the ground, and contextually embedded, as in, 'is it true that this or that happened then and there?'. If we avoid the word 'truth' and instead emphasise the credibility of the newspaper we miss a critical point: we do not want the newspaper to be credible, believable or 'probable/possible' as we do with fiction; we want it to be true or truthful. Though both fiction and newspapers require extensive mediation to deliver a believable account, newspapers need more than what goes on in the head of the reader. Their truth depends upon instituted systems for news gathering, and an emphasis upon truth can be heard in justifications of even the most implausible news items: 'this truth is stranger than fiction', 'you can't make this stuff up!. Therefore, every newspaper must satisfy questions like the following. Have events been recorded accurately? Have they been transmitted 
through space and over time without distortion? Because translating events into news involves this intricate set of mediations, news is vulnerable to scepticism about its truthfulness. For newspapers to emerge as the most robust and inclusive and persistently available source of news on matters of public concern, they had to earn the newspaper readers' trust that their accounts of the news were true. How did the early developers of the newspaper succeed in establishing that trust?

To explore these related questions, I will need to steer clear of the Scylla and Charybdis of newspaper history. Two grand narratives explain the rise of the newspaper by idealising and simplifying that history. The progressive narrative understands the newspaper as an engine that promotes the rise of literacy, an informed public, a public sphere of private citizens, and popular participation in government. This narrative sidesteps the question of truth and trust by assuming that both are the inevitable by-products of the newspaper's steady improvement. Like all Whig narratives, it knows where history is headed and is therefore rigorously teleological: it interprets early developments in the light of later achievements. This narrative, by pointing, for example, to the pivotal role that newspapers played in the American and French Revolutions, becomes a vector that points towards (without yet getting to) the liberal democratic societies of the nineteenth and twentieth centuries. Because such an outcome is claimed to depend upon the free circulation of diverse opinions, this progressive narrative promotes the freedom of the press as an idea that slowly emerges in the eighteenth century, becomes enshrined in law by the First Amendment of the us Constitution (ratified in 1791), and serves as a keystone of the claim for other kinds of freedom (including the abolition of slavery, women's suffrage, and union organising). ${ }^{1}$ This classically liberal account is

1 While the progressive narrative gets its fullest development in the nineteenth and twentieth century, the struggles around press censorship in Britain in the 1770 s present early examples of a rights-based argument for press freedom. Sometimes these arguments are reprinted in the newspaper. The Virginia Gazette of 24 December 1772 (printed by Purdie) reprinted a long speech by John Wilkes, insisting that "Our right, as constituents, to be fully informed of the proceedings of our representatives in Parliament, has been clearly demonstrated". The Virginia Gazette of 8 January 1776 (printed by Gaine) reprinted extracts from the 'Association' founded at the Globe Tavern on Fleet Street devoted to protecting the 'Liberty of the Press'. To justify their Association, the members offered general principles defending press freedom: (a) that "freedom of the press is indispensable to ... free government"; (b) "that by a judicious exercise of the freedom of the press, the minds of men are enlightened" and "knowledge, both civil and religious, is diffused"; (c) "the people are taught to prize, as inestimable, those political rights secured by the REVOLUTION [of 1688]". 
given an especially idealised turn when it is argued that the newspaper's glory is realised upon those occasions when it speaks (capital-T) Truth to Power. ${ }^{2}$

An alternative history of the newspaper begins by pointing out that the early newspapers were not started to embody Truth, but to support two more prosaic activities: commerce and governance. The propaganda narrative throws the rise of the newspaper into a more sceptical light by emphasising the essentially commercial underpinnings of the newspaper's origins, and it links newspapers' rise to the expanding political power of governments, which sponsored, censored or shaped many early newspapers. The power of economic elites benefited from the services that newspapers provided to the expanding global commercial empires that emerged during the years between 1600 and 1900. In this sceptical narrative, the newspaper has always been an instrument of propaganda, in its twentieth-century sense as the mendacious manipulation of the opinion of the less informed. Although Lord North did not have the twentieth-century concept of propaganda available to him, his characterisation of the newspapers anticipates later scepticism about the truth claims of the newspaper. In a speech to Parliament in April 1776, where he introduced a fundraising bill to double the tax on newspapers, he characterised newspapers this way: the newspapers circulate the idea "that the liberties of this country were in danger from cruel, ambitious, and tyrannical ministers," and their falsehoods "were propagated and repeated in the course of a year, in no less than $12,230,000$ newspapers". ${ }^{3}$ In the propaganda narrative, newspapers feign truth to win trust in whatever ideology is most useful to those who control the media. So, for example, the early newspapers' claim to neutrality and disinterestedness is the ruse that conceals the ideological agendas that it promotes, most especially the notion that the newspaper sustains its readers as free and rational subjects. Within the propaganda narrative, the early newspaper's coverage of spectacular events - violent wars and revolutions, crime, scandal and disasters - anticipated the later emergence of the news as a form of entertainment with an appeal far beyond its early audience of political and economic elites. In the nineteenth and twentieth centuries, Marxist, fascist and liberal critics - from Karl Marx and Adolf Hitler to Walter Lippmann, Edward Bernays

2 Michael Schudson, The Power of News (Cambridge, MA: Harvard University Press, 1995). In the essay 'Watergate and the Press' (ibid., pp. 142-165), Schudson offers an account of how the heroic agency of the newspaper gets a boost from episodes like the Watergate affair.

3 New York Gazette, 18 November 1776. For a more sympathetic discussion of the newspapers' tradition of "documenting public criticism of established governments" see Jeremy D. Popkin, News and Politics in the Age of Revolution:Jean Luzac's Gazette de Leyde (Ithaca: Cornell University Press, 1989), p. 15. 
and Noam Chomsky - developed this sceptical account of the newspaper as a vehicle of propaganda, which offers an 'ad for the status quo'.

Neither of these narratives - one, too idealistic, and the other, too sceptical is simply wrong. Both emerge from and offer insights into the newspaper's complex history. But to understand how the eighteenth-century newspaper of Britain and its colonies developed into a trustworthy source of public information, it is essential to avoid the synthetic simplification of the progressive story of newspapers' inevitable rise as well as the resolute scepticism of the propaganda narrative's ideology critique. By pursuing a historical and formal analysis of the Anglophone newspaper that emerged in the eighteenth century, I will explore the means by which the early newspaper earned their readers' trust in the truthfulness of the information that they transmitted. A detailed analysis of the rhetorical and formal means by which newspaper editors strove to win the trust of readers will help us avoid the bias of developmental models, which assume that the newspaper necessarily improved with the passage of time. The eighteenth century was the middle epoch of the modern newspaper: $a f-$ ter the early seventeenth-century manuscript newsletters and the first printed gazettes, as formulated most successfully in the Netherlands and copied elsewhere, but before the nineteenth-century development of the newspaper editor as the conductor of the newspaper as a vehicle of party politics. Although the printers of the eighteenth-century newspaper often strove for impartiality, they were very far from the modern reporter, who, writing in the first person from a particular place and time, underwrote the newspaper's claim to present the news objectively. ${ }^{5}$

The expanding influence of the Anglophone newspaper over the course of the long eighteenth century was neither a plan of government nor the preconceived design of commercial interests. More like emergence within a complex system, it resulted from the combined effects of a series of independently motivated developments between 1665 and 1800 . Each contributed to enabling the newspaper to emerge as the most flexible and authoritative way to transmit news across distances. First, there was a steady improvement in the reliability, scope and speed of the postal system, which supported the global distribution of the Anglophone newspaper. Secondly, the improvements in the physical

4 See Max Horkheimer and Theodor Adorno, Dialectic of Enlightenment (1944), trans. John Cumming (New York: Continuum, 1982), especially 'The Culture Industry: Enlightenment as Mass Deception', pp. 120-167.

5 Jeffrey L. Pasley, "The Tyranny of Printers": Newspaper Politics in the Early American Republic (Charlottesville, va: University Press of Virginia, 2001), pp. 2-3; Schudson, Power of News, pp. 108-109, 141. 
and human infrastructure for the circulation and sharing of newspapers which included turnpikes and packet ships, clubs and coffeehouses, and the growth in literacy - expanded newspaper readership. Thirdly, while successful newspapers became more vulgarly popular, their increased wealth and autonomy enabled them to have recourse to the law to protect themselves against government censorship as seen in the trials seeking to punish John Wilkes and suppress the Junius papers. ${ }^{6}$ Fourthly, over the course of the century, newspapers became more numerous, larger in paper size and print-run, and published with greater frequency. These very significant increases in number and quantity enhanced the scope and extent of the newspaper's influence. Finally, it became a commonplace to say that the newspaper encouraged appeals to the "tribunal of the public". ${ }^{7}$ In spite of the limitations of Habermas's account of the public sphere, the wide distribution of newspapers - carrying detailed accounts of politics, war and revolution - invited private citizens to exercise their independent judgment on matters of public concern. Whether or how often readers availed themselves of the critical independence that the newspapers afforded was, and still is, a matter of lively debate.

\section{Building Credibility: The Early Newspaper as an Inchoate Mixture of News Items}

The newspaper was the ugly duckling of early print media. Compared with books, systematic treatises, and even topical and polemical pamphlets - that is, any genre of writing that has a through-narrative that blends and reconciles parts into the whole - the eighteenth-century newspaper appears as an unblended mixture of differently sourced news items. The gathering of the discrete and different is the most distinctive formal feature of the newspaper. The same page might juxtapose a reward for an escaped slave, an advertisement for books and the king's speech opening Parliament. Letters, articles, advertisements, and grain prices are assembled in an additive, disconnected fashion and organised with such a weak principle of subordination that their rhetorical

6 See Troy O. Bickham, Making Headlines: The American Revolution as Seen through the British Press (DeKalb: Northern Illinois University Press, 2009). Bickham documents the way the enormous profits of the big London newspapers meant that the Public Advertiser (one of the 9 dailies among 19 London newspapers) could afford, with its circulation of over one million in 1771 , to offend government by publishing the Junius Papers and still successfully protect themselves from the legal prosecution (ibid., pp. 22-23).

7 Popkin, News and Politics, p. 42. 
effect is paratactic. ${ }^{8}$ Even the general principles of the gazette layout - the distant goes before the near; the earlier before the latest news - had to be reconciled with a typesetter's imperative, whereby the front and back page carried what the printer received first, and the middle pages carrying the 'freshest' news. ${ }^{9}$ When compared with the newspapers of the nineteenth and twentieth century, the eighteenth-century newspapers lacked the indirect formal means that editors later developed to organise the news: putting the most important news items on the front page; reducing a news item to a kernel and shouting it to the reader with a headline; and separating opinion from fact, so as to sequester opinion on the editorial page. In short, when compared with the newspapers to come, the eighteenth-century newspaper had a list-like lack of order. In a sense, every newspaper was a 'magazine', in the literal sense of a collection or gathering, where diverse items were linked and separated by the thin black lines of the column dividers.

Though mixture was a challenge to the newspaper's coherence, and it has no overt bearing upon the newspaper's truthfulness, by accommodating variety, mixture became a source of strength. In The News-Paper: A Poem, George Crabbe celebrates mixture and variety as a trait that explains the newspaper's appeal to diverse readers:

This, like the public inn, provides a treat, Where each promiscuous guest sits down to eat;

And such this mental food, as we may call,

Something to all men, and to some men all. ${ }^{10}$

The promiscuous mixture of the commercial eighteenth-century newspaper not only meant that it had the potential to accommodate whatever news items and writings pleased its subscribers. By reprinting diverse news items in a routine fashion, newspaper editors could deflect suspicion of their bias.

\section{'The Uncertain Medium'}

Historians of the book like Elizabeth Eisenstein and Adrian Johns have shown that belief in the 'intrinsic reliability' and truth-value of the printed book,

8 William B. Warner, Protocols of Liberty: Communication Innovation and the American Revolution (Chicago and London: University of Chicago Press 2013), p. 126.

$9 \quad$ Popkin, News and Politics, Chapter 5.

10 George Crabbe, The News-Paper: A Poem by Reverend George Crabbe, Chaplain to His Grace the Duke of Rutland (London: 1785), pp. 15-16. 
especially early modern science books, could not be assumed but had to be 'made..11 This could be done through printing practices, like standardisation and fixity, ${ }^{12}$ or through the patronage of the great, the carefully constructed persona of the author, elaborately staged polemics, or institutional support. ${ }^{13}$ To establish the newspapers' truthfulness, the printer of commercial newspapers had few of these resources. In fact, the early newspaper had an explicitly discussed credibility problem. For example, in 1773, two years before the beginning of the American War, Richard Henry Lee wrote to Samuel Adams requesting information regarding the British commission appointed to investigate the burning in Rhode Island of the customs ship HMS Gaspee. Lee despairs of ever having "a just account of this affair ... at this distance, and through the uncertain medium of the newspapers". ${ }^{4}$ The request implies that the gold standard for credible news was the news transmitted by private letter between trusted correspondents. ${ }^{15}$ In fact, the credibility of the newsletters that thrived during the seventeenth and early eighteenth century, may have benefitted from having been written in manuscript by a news gatherer with a reputation for reliability. By contrast, The Edinburgh Evening Post of 4 August 1783 published this satiric mediation on the unreliability of the printed newspapers: "the four winds (the initials of which make the word NEWS) are not so capricious, or so liable to change, as our public intelligences". No wonder, this observer concludes, the newspaper must qualify the truthfulness of its information by reminding readers of the newspaper printers' dependent relationship to scattered news sources: "we hear; they write; it is said; a correspondent remarks, with a long list of ifs and supposes". Doubts about the truthfulness of newspapers' accounts were difficult to put to rest. However, over the course of the eighteenth century, printers of Anglophone newspapers, working within a competitive and inventive media environment, developed a number of ways to enhance the credibility of the newspaper.

\footnotetext{
11 Adrian Johns, The Nature of the Book: Print and Knowledge in the Making (Chicago: University of Chicago Press, 1998), pp. 2-3.

12 Elizabeth L. Eisenstein, The Printing Press as an Agent of Change: Communications and Cultural Transformations in Early-Modern Europe (Cambridge: Cambridge University Press, 1979).

13 Johns, Nature of the Book.

14 James Curtis Ballagh (ed.), The Letters of Richard Henry Lee, Volume I: 1762-1778 (New York: MacMillan, 1911), p. 82.

15 Richard Henry Lee was in fact writing to the Boston Whig best connected to timely information. Samuel Adams was in correspondence with the Deputy Governor Sessions of Rhode Island about how best to respond to the formation of a Royal Commission to investigate the burning of нмs Gaspee.
} 


\section{Trust 1: Distributed Responsibility}

If questioned as to the accuracy of a news item in their paper, most printers had a ready reply that qualified their personal responsibility: 'I just reprint the news items from the papers delivered to me by post'. This is an alibi in the most literal sense of 'being elsewhere'. It displaces responsibility for the truth of an account from the local newspaper printer to the distributed newspaper network from which it has been copied. The free posting (i.e. franking) of copies within the newspaper cultures of Britain and America, along with an absence of copyright produced a de facto news commons from which newspaper printers could freely select. This is why, with the notable exception of local advertising, the vast majority of newspaper content consisted of reprinting of writing penned elsewhere. The trustworthiness of each newspaper depended upon the truthfulness of the whole network of newspapers. The accuracy of the account of the birth of an heir in St. Petersburg, of the battle in the Netherlands, of the hurricane in Jamaica, or of the riot in Boston would necessarily depend upon the accuracy of the first newspaper that printed the news item. The structure of the news network meant that inaccurate accounts were submitted to an analogue form of error correction. Before the newspaper had developed, false news could thrive for extended periods of time. Thus, the Spanish Consul in Rome spread false news that the Spanish Armada had prevailed over the English fleet in the summer of $1588 .{ }^{16}$ However, if we entertain the counterfactual existence of the eighteenth-century newspaper network in the sixteenth century, the Spanish Consul version of events would have been quickly challenged by very different newspaper accounts. The existence of the eighteenth-century newspaper's distributed news network meant that readers could gravitate to newspapers that offered the most timely and accurate news sources. While newspapers often collaborated with each other, they published in a competitive environment where consistently unreliable news sources and newspapers would wither. Therefore, from the earliest newsletters and newspapers, a concern for the truthfulness of the news became embedded in guild values and practices. Long before the modern era, it was accepted that " $[t]$ he most valuable asset a paper has is its credibility". ${ }^{17}$

16 Andrew Pettegree, The Invention of News: How the World Came to Know about Itself (New Haven and London: Yale University Press, 2014), pp. 151-163.

17 Twentieth-century editor of the Baltimore Sun, quoted in Schudson, Power of News, p. 5 . 


\section{Trust 2: The Neutral Tone or the Mask of Character}

The newspaper editors of the eighteenth century consciously avoided an earlier use of news to discredit the doings of the 'great': the cruelty and innuendo of political satire and the sexual licentiousness of the gossip-mongering scandalous chronicles, such as Delarivière Manley's The New Atlantis (1709). Instead, the earliest printed gazettes stuck "closely the model of the manuscript news-letters",18 where brief, factual news items, which were gathered from diverse locations, could be distributed to subscribers. Newspaper editors, like Jean Luzac of the Gazette de Leyde, assumed the sober posture of an historian, whereby "journalist and reader became partners in the difficult discovery of the truth about contemporary history". ${ }^{19}$ Eschewing the spectacular and the hyperbolic, the news writer gravitated to the plain style which Bacon advocated for the New Science. In an article entitled 'Gazetier' for the Encyclopédie, Voltaire described the valuable restraint of the newspaper writer: "a good gazetteer should be promptly informed, truthful, impartial, simple, and correct in his style; this means that good gazetteers are very rare". ${ }^{20} \mathrm{~A}$ similar point is made somewhat later by Baron Jacob Friedrich von Bielefeld: gazette writers should limit themselves to "a clear, truthful and succinct narration of public events. ... A gazetteer who comments is a vulgar person. ... [He should] leave to his readers the business of making reflections".21

While newspapers of the eighteenth century accurately reported facts, they also trafficked in a broad spectrum of opinion. For this vein of writing, rather than imitating the list-like structure and stylistic restraint of the manuscript newsletters, newspapers drew upon more literary models of satire and essay to develop the lively opinion conveyed by compelling authorial personae. This enhanced the credibility of the moral and political writing that has been part of the newspaper since the early eighteenth century. From the moral essays of Mr. Spectator (wise, knowledgeable and witty) to the political engagement of Cato's Letters (fierce in his defense of liberty and public virtue) to John Dickinson's Letters from a Farmer in Pennsylvania (with its calm, urbane and gentlemanly scholarship), readers were invited into an informal conversation, where the trustworthiness of ideas was enhanced by the charismatic persona who 'spoke' them. During the agitation that led to the American Revolution,

\footnotetext{
18 Pettegree, Invention of News, p. 184.

19 Popkin, News and Politics, p. 98.

20 Ibid., p. 127.

21 Ibid., p. 127.
} 
one Whig leader, Samuel Adams, published under many different pseudonyms. Each name implied a specific intellectual posture and supported a different style of address. As 'Cotton Mather' and 'Puritan', Adams recalled Bostonians to their earliest religious values; as 'Vindex' or 'Cato' or 'Valerius Poplicola', he conjured the austere republican virtues of early Rome; as 'Candidus' and 'Determinatus', he challenged the tyranny of British officials. ${ }^{22}$ The anonymity of much of the writing published by the eighteenth-century newspaper taught readers to sift and evaluate the ideas of strangers.

\section{Trust 3: Openness and Inclusiveness}

The surest way to convince readers of a paper's disinterestedness was to be inclusive. At least three colonial American newspapers used the same words on their masthead: "Open to all PARTIES - not under the influence of $A N Y$ " ${ }^{23} \mathrm{~A}$ paper run on an 'open' system asserted a brave independence from 'influence', contempt for the narrowness of faction, and an assumption that discovering truth was a collaborative enterprise. As Crabbe's poem suggests, newspapers were open and public in the same way that stage coaches and public houses were. This placed a practical limit upon the printer's control of the truthfulness of the words he prints. He, like the innkeeper, must stay open to many speakers of diverse opinion. In an 'Apology for Printers', Benjamin Franklin describes the openness of the operational protocols that he observed in his print shop and now invited newspaper readers to accept. First, it was "unfair for the reader to expect to be pleased by all that is printed". Printers were trained that when men differ, "both sides ought equally to have the advantage of being heard by the public" because, in an echo of Milton's Areopagitica, "when truth and error have fair play, the former is always an overmatch of the latter". Secondly, because of the detachment from partisanship their profession required, printers of opinion "naturally acquire[d] a vast unconcernedness as to the right or wrong opinions contained in what they print". Cultivating phlegmatic neutrality, they printed "things full of spleen and animosity, with the utmost calmness and indifference". Finally, if they were to print only what they themselves believed and approved, "an end would thereby be put to free writing"; and alternatively, if they "determined not to print any thing ...[but what] would offend

\footnotetext{
22 Ira Stoll, Samuel Adams: A Life (New York: Free Press, 2008), p. 59.

23 This identical language is used in the pre-revolutionary period by Isaiah Thomas's Massachusetts Spy [Boston], the Connecticut Current [Hartford], and, with a slight variation in language, Rind's Virginia Gazette [Williamsburg].
} 
no body, there would be very little printed". ${ }^{24}$ Franklin never quite says what his operational protocols imply: on matters of truth and lies, readers of the news had to judge for themselves. Scholars of the early American newspaper, like Charles Clark and James Green, have shown that the openness and tolerance that Franklin advocates was often motivated by a canny commercial strategy: it avoided driving away advertisers and, as a general repository of all essential news, inclusive reprinting discouraged readers from subscribing to rival papers. ${ }^{25}$

\section{Weakness become Strength}

There are several paradoxes evident from the development of the eighteenthcentury newspaper. The first was the success of the commercial papers - with their messy plurality, variety and abundance - over the well-ordered messaging of the court gazettes. In this competition for the faith of readers, court gazettes like the Gazette de France and the London Gazette started with many advantages: access to state information, ample subsidies, capable writers, the authority to publish their nation's newspaper of record and immunity from censorship. But, because their news expressed a pro-state bias, because their evident aim was to glorify the monarch and secure the loyalty of subjects, and because they censored facts and opinions that failed to support these purposes, the court gazettes earned the scorn of readers. ${ }^{26}$ By contrast, the very qualities of the eighteenth-century commercial newspaper that seemed to vitiate its credibility broadened its influence. Its mixed and heteroclite principles of (dis)organisation, and its resulting lack of conceptual unity, enabled the

24 Apology for Printers, Pennsylvania Gazette, 10 June 1731.

25 See Charles E. Clark, The Public Prints: The Newspaper in Anglo-American Culture 1665-1740 (New York: Oxford University Press 1994), and James N. Green, 'English Books and Printing in the Age of Franklin', in Hugh Amory and David D. Hall (eds.), A History of the Book in America, Volume I: The Colonial Book in the Atlantic World (Cambridge: Cambridge University Press, 200o), pp. 248-297.

26 The Gazette de France did not see fit to publish an account of the storming of the Bastille on 14 July 1789 . Of course it is not difficult to imagine why the government would be reluctant to use its communications apparatus to spread this inflammatory news. But both the Gazette de France and the London Gazette also declined to report upon the ceremony, held in September 1791, when the King Louis XVI signed the French Constitution. See Kristiansen in this collection. Active censorship like France's discouraged publication for there, as a contemporary complained, a "journal [is] reviewed, corrected and castrated by the Paris censors" (Popkin, News and Politics, p. 41). 
commercial newspaper to grow into a broad and accommodating channel for news and opinion. The periodicity of the newspaper afforded the same paradoxical blend of weakness and strength. While the newspapers' special claim was to "give the first report" of the news, ${ }^{27}$ these reports - because of strict deadlines and limitations of space - were often incomplete, of dubious accuracy, and uncertain significance. But precisely because of its periodicity, the newspaper made the implicit promise that each account is oriented toward the more correct, complete and meaningful account to come. The news of an unfinished event drew readers into a very lifelike suspense as to how a news story would end. Finally, "by giving [readers] a sense of the movement of the wider world", newspapers often transmitted surprising and unsettling events. But, by promptly naming and recording them, the newspapers also provided a "comforting framework" for the reader. ${ }^{28}$

\section{A Case Study: The Boston Gazette Transmits a True Enough Account of the Day after the Boston Massacre}

When the American Crisis opened in 1765 with the organised resistance to the Stamp Act, the newspaper proved to be a supple and resilient medium for the transmission of public information. The political crisis that unfolded over the following decade offers a test case for assessing the accuracy and truth-value of the Anglophone newspaper. It is an old adage of newspaper history that customary standards of neutrality quickly fade in times of revolution and civil strife. Thus, one might assume that the Whig-Patriot sympathies of the Boston Gazette would lead that newspaper to offer a one-sided view of the aftermath of what is later called 'the Boston Massacre'. On 5 March 1770, a platoon of British regulars came to the aid of a sentry, who was being harassed by a crowd of angry apprentices and seamen. The confrontation escalated until the troops fired their muskets, leaving four of the inhabitants of the town dead, and at least seven others seriously injured. British officials were sure it was selfdefence, while the members of the Boston Town Meeting quickly called it 'a massacre'. The Boston Gazette's account of the deliberation on the day after the event was restrained by the narrative conventions of the eighteenth-century newspaper: a reliance upon official documents; avoidance of the swirl of partisan opinion; and provision of a spare and accurate presentation of persons, places, and events. On Monday 12 March, the Boston Gazette printed the most

27 Popkin, News and Politics, p. 7.

28 Ibid., pp. 6-7. 
complete and coherent public account of the massacre that was published at the time. It included a brief history of the eighteen-month occupation of Boston by British troops as well as accounts of the deaths on King Street (on 5 March), of the deliberations leading to the troops' removal (on 6 March), and of the huge funeral procession held in honour of the victims (on 8 March). ${ }^{29}$ This detailed account contrasts with the previous Thursday's issue of the Tory Boston News-Letter, which had carried only a short three-paragraph account that asserted the fact of a shooting on King Street, offered a list of victims, and quoted Governor Hutchinson's reassuring words to the crowd assembled outside the Town-house "promising to do all in his power that justice should be done". ${ }^{30}$ By contrast, the Boston Gazette's intricate synthetic narrative required two full pages, which was secured by publishing a two-page supplement to their standard four-page paper.

The Boston Gazette's coverage is balanced between an explicit expression of sympathy for the victims of 5 March and a restrained citation of the words exchanged in debating what should be done on 6 March. Thus, the columns recounting the events were published with a special border in mourning black (see Figure 1.1). In addition the four victims were further honoured with an engraving of the four funeral caskets. To secure the reader's sympathy for the victims, the coverage begins by pointing to the indelible residues of British violence: "Tuesday morning presented a most shocking scene, the blood of our fellow citizens running like water through King-Street and the merchants Exchange ... Our blood might also be track'd up to the head of Long Lane, and through divers other streets and passages". The use of the possessive pronoun 'our' draws the reader into a shared predicament. If this blood on the streets of Boston is our blood, then the town is one body to which we all belong. While the blood evidences British brutality, it also sanctifies the town's unity.

This beginning makes quite explicit that the Gazette's basic point of view coincides with that of the Boston Town Meeting, rather than the Governor or the soldiers who had occupied the town eighteen months earlier. Yet this issue of the Gazette quickly mutes the pathos of its coverage, reflecting the confidence, embedded in newspaper writing, that sticking to what happened and focusing upon the dramatic uncertainty of the rush of events was the surest way to establish the interest and authority of its account. So the Gazette does not offer first-person testimonials of what happened on 5 March, nor does it publish essays explaining the political implications of the violent deaths. Instead, the Gazette avoids obvious bias with an elegant solution: it interweaves

29 Boston Gazette, 12 March 1770.

3o Boston News-Letter, 8 March 1770. 
I. Bleeding Body of the Town: "a most shocking scene, the blood of our fellow citizens running like water through King-Street and the merchants Exchange...Our blood might also be track'd up to the head of Long Lane, and through divers other streets and passages."

\section{The Town Meeting Takes the Initiative (11AM} Meeting): a "vote" is passed and carried by "a committee of 15 respectable Gentlemen" to "the Lieutenant Governor in Council" : "THAT it is the unanimous opinion of this meeting...that nothing can rationally be expected to restore the peace of the town \& prevent further blood and carnage, but the immediate removal of the Troops;..."

\section{His Honor's Reply: "I AM extremely sorry for the} unhappy differences between the inhabitants and troops, I have exerted myself upon that occasion that a due inquiry be made, and that the law may have its course... [Since the regiments] have their orders from the General in New York. It is not in my power to countermand those orders. ..." However, the $29^{\text {th }}$ Regiment will be moved to the Castle and the main guard removed from King Street.

IV. Town's response (3PM Meeting): "the question was put, Whether the Report be satisfactory? Passed in the negative, (only a dissentient) out of upwards of 4,000 votes. It was then moved and voted that a committee of John Hancock, Esq.; Mr. Samuel Adams, Mr. William Mollineux, Williams Philips, Esq.; Dr. Joseph Warren, Joshua Henshaw, Esq.; and Samuel Pemberton, Esq. be a committee to wait on his Honor the Lieut. Governor, and inform him, that it is the unanimous opinion of this meeting that" the reply of His Honor "is by no means satisfactory; and that nothing less will satisfy, than a total and immediate removal of all the Troops."

\section{The Council deliberates and finds a Solution (3 voices):} 1: The Lieutenant-Governor lays before the Council the 'vote' of the Town of Boston;

2: The Council is "unanimously of opinion, 'that it was absolutely necessary for his Majesty's service, the good order of the Town, and Peace of the province, that the Troops should be immediately removed out of the Town of Boston.

3: Col Dalrymple "now gave his word of honor that he would begin his preparations..." for the "removal of both regiments to the Castle."

Epilogue: the Town Meeting savors its Victory and takes charge: The Inhabitants express "high satisfaction;" \& "for the security of the Town in the Night" they set a "strong Military Watch."
Boston Gazette: the Events on March 6, 1770

after fome animated fpeeches becoming the occafion, they chofe a Committee of 15 refpettable Gentlemen to wait upon the Lieut. Governor in Council, to requeft of him to iffue his Orders for the immediate removal of the troops. The Meffage was in thefe Words:

'THAT it is the wnanimoart opinion of this meeting that the

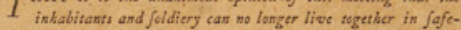
ty; that nothing can rationally be expelied to refore the peace of the town \& prevent further blood \& carnage, bat the imendiate removal of the Troops; and that soe thercfore mef fervent'y fray his Honer that his poster and infitunce may be exerted for thair inffant removal.

His Honor's Reply, which was laid before the Town then Adjourn'd to the Old South Meeting-Houfe, was as follows,

Gentlemen,

IM extremely forry for the inkappy differences betwoen the $I$ imbabitants and tropps, and s/pecially for the celien of the laft exesting, and I have ceverted myfalf upos that occeffion that a dive engatiry may be made, and that the laso may have ins pourfe. I have in couscil confulited swith she commanding offecers of the tewo regiments who are in the tseun. They have their corders from the Gentral at Nese-York. It is not in my poever to ceanter.

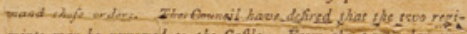

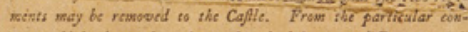
cern so hich the 29 th rogiment has bad in year differences, Col. Dalrymole solo is the comnaranding officer of the troops has Signifed that, that regimert ball evithout delay be placed in the barracks at the Coflie wntil be can fend to the Gemeral and receive his further, orders concerning both the rogiments, and that the nain guard foall be removied, and the 14 ph regiment fo dispofed and laid ander fach reftrinist that all occafion of future dijpurb. asces magy be prevented.

The foregoing Reply having been read and fully confidered -the queftion was put, Whether the Report be fatiffatory Paffed in the Negative, (only I diffentient.) out of upwards of 4000 Voters.

It : was then mored and voted John Hancock, Efg; Mr. Samuel Adams, Mr. William Molineux, Willian Phillips, Efg; Dr. Jofeph Warren, Johus Henfiaw, Efg; and Samuel Pemberton, Efgi bè a Committee to wait on his Honour the Lieut. Governot, and inform him, that it is the unanimots Opinion of this Meeting, that the Reply made to a Vote of the lahabitunts prefented his Honor in the Mosning, is by no Means fatisfactory; and that nothing lefs will fatisfy, than a total and immediate remoyal of all the Troops.

The Cornmittee having walted upon the Lieut. Governor agrecable to the foregoing Vote; laid beiore the Inhabitants the following Vote of Council received from his Honos.

His Honor the Lieut. Governor laid before the Board a Vote of the Towa of Bofton, paffed this Afternoon, and then addreffed the Board as follows,

Gestlenten of the Couscil,

"I lay before you a Yote of the Town of Botton, which I have joft now received form them, and I tow zk your $A d$. vice what you judge neceitary to be done upon it."

The Council thereupon expreffied themfelvef to be ananimoukf of opinion, "that it was abfolutely neceffary for his Majeity's fervice, the good order of the Town, and the Peace of the Province, that the Troops ficuld be immediately removed out of the Town of Botton, and thereupon advifed his Honor to comanuaicate this Advice of the Council to Col. Dalgymple, and to pray that he would order the Troops down to Caftie-Williarn." The Conmittee alfo informed the Town, that Col. Dairymple, alter havieg feen the Vote of Council, faid to the Committee, "That he now gave has word of, Honer that he would begin his Preparations in the Morning, and that there fhould be no unneceffary delay until the whole of the two Regiments were removed to the Caftle." Upon the above Report being read, the Inhabitants could not avoid exprefling the high Satiafaction it afforded them.

After Meafures were taken for the Security of the Town in the Night, by a ftrong Military Watch, the Meeting was difolved.

FIGURE 1.1 The Boston Gazette's account of the events of 6 March 1770. 
official documents of the meetings into a lucid and suspenseful dialogue between the Governor, the Town Meeting and the Council. Rather than engage in narrative diegesis (by telling), the Boston Gazette offers a narrative mimesis by showing what happened on 6 March. Because this reproduces the presentational mode of drama, I will describe this newspaper coverage as a five-act play, where each exchange between Whigs and Royal Officials appears as a deed in the form of words, that is, a speech act with performative force (see Figure 1.1).

Act 1 : To respond to this crisis, the Town Meeting, gathered in large numbers at Faneuil Hall, appointed a committee of fifteen respectable gentlemen to carry the resolution to Governor Hutchinson, who was meeting nearby in the Town House with the Council. The Town Meeting's resolution is presented by the committee to the Council:

THAT it is the unanimous opinion of this meeting that the inhabitants and soldiery can no longer live together in safety; that nothing can rationally be expected to restore the peace of the town \& prevent further blood and carnage, but the immediate removal of the Troops; and that we therefore most fervently pray His Honor that his power and influence may be exerted for their instant removal.

Notice that this resolution lacked any reference to the event (the deaths on King Street) that occasioned it. The Town Meeting apparently knows that any reference to or denomination of the previous night's event will become an occasion for dispute and delay. Instead there is a blunt statement of an opinion"that the inhabitants and soldiery can no longer live together in safety" - plus a prediction that carries a threat: that only "the immediate removal of the troops" can "prevent further bloodshed and carnage". The resolution ends on a pragmatic note: knowing the Town Meeting does not have the authority to remove the troops, they cast this resolution into the form of a petition to the Governor "we therefore most fervently pray ... for their instant removal". Because it succeeded in setting the terms for the day's debate, this resolution had enormous influence.

Act 2: The Governor's reply expresses sorrow for the previous night's conflict (which he sagely refuses to characterise), makes a commitment to the law, but then rejects the resolution's request, insisting that as Governor, he does not have the "power" to order the removal of the troops.

I AM extremely sorry for the unhappy differences between the inhabitants and troops, I have exerted myself upon that occasion that a due inquiry be made, and that the law may have its course ... [The regiments] have their 
orders from the General in New York. It is [therefore] not in my power to countermand those orders.

However, the Governor fashions this compromise: he tells the troops' commander, Colonel Dalrymple, that he would not object to the removal from Boston of one of the two regiments.

Act 3: Reconvening the Town Meeting in the afternoon, in the larger space of Old South Church, the Meeting quickly responded: all but one of the four thousand in attendance voted that the Governor's response is not "satisfactory". "It was then moved and voted" that seven members of the meeting "be a committee to wait on the Governor, and inform him that it is the unanimous opinion of this meeting", that his reply to the Town's vote of this morning "is by no means satisfactory; and that nothing less will satisfy, than a total and immediate removal of all the Troops". Note that the town meeting's authority is strengthened by its exact observance of proper procedures. The same is true for the Governor.

Act 4: The Governor asks the "the Gentlemen of Council" for their advice, the Council is "unanimously of opinion ... that the Troops should be immediately removed out of the Town of Boston"; and finally, breaking the apparent impasse between the Governor and the Council, the military commander of the regiments, Colonel Dalrymple, "gave his word of honor that he would begin his preparations" for the "removal of both regiments to the Castle" without "unnecessary delay".

Act 5: The account ends back at the Town Meeting. "Upon the above Report being read, the inhabitants could not avoid expressing the high satisfaction it afforded them". They take "measures for the security of the town in the night by a strong Military Watch".

By weaving its account with an exact citation of the words spoken or written on 6 March, the Gazette's narrative braids a storyline out of available textual objects, the indisputable factual kernels of the day. While most of the words are copied out of the minute book of the Boston Town Meeting, this source has been abridged to create an illusion of an up-tempo flow of a dialogue between the Town and the Governor, with a critical final act of mediation by the Council. Through the directness and simplicity of this dialogue, the Boston Gazette eschewed polemics or abstract principles, commentary or explanation, or any tendentious speculations about motive. The coverage succeeds in specifying a factual common ground to which most readers could assent. This is the truth with a small t. The even-handedness and fidelity of the account is confirmed three days later when the Tory News-Letter, printed by Richard Draper, publishes a verbatim reprint of the Boston Gazette's account of 6 March. 
However, this account hides as much as it represents. While the Boston $\mathrm{Ga}$ zette's account is broadly accurate, there is one glaring gap in the narrative. Many readers must have wondered why the Governor changed his mind on the critical question of troop removal between the morning and afternoon meetings of the Council. One might defend the incompleteness of the $\mathrm{Ga}$ zette's coverage by noting that facts are numberless and reality illimitable. But the Gazette's omission is most consequential. The substance of the Council's secret deliberations was reported by letters to the American Secretary Lord Hillsborough in Whitehall after the meeting. In the three long letters, sent by Governor Hutchinson, Secretary Oliver, and Lieutenant-Colonel Dalrymple, three critical (and even scandalous) moments of the meetings are described: first, when the morning committee of fifteen had warned of a violent popular uprising, the Governor had issued a stern warning: that any who resorted to force would be guilty of treason, "and their life and property would be forfeit to the Crown". Secondly, in reply to the Governor's compromise offer to remove one regiment, Samuel Adams had offered this sharp rejoinder: "Mr. Adams, one of the committee, told Colonel Dalrymple that if he could remove the 29th Regiment he could also remove the 14th, and it was at his peril if he did not". ${ }^{31}$ Finally, and most significantly,

Councilor Royall Tyler insisted that if the troops were not removed that the people would come in from the neighboring towns, and that there would be ten thousand men to effect the removal of the troops, and that would probably be destroyed by the people, should it be called rebellion, should it incur the loss of our charter, or be the consequences what it would. ${ }^{32}$

What proved decisive to the deliberations and led all the Council, including the Governor's close ally and brother-in-law Andrew Oliver, to abandon Governor Hutchinson was the conviction that militia from the surrounding towns were 'in motion' to remove the Royal troops from Boston by force. Then there would have been a real Boston massacre.

It is not known how soon the Whigs of the town meeting learned of the private deliberations of the Council. ${ }^{33}$ This background information - from

31 K.G. Davies (ed.), Documents of the American Revolution, 1770-1783, Volume II (Dublin: Irish University Press, 1975), p. 53.

32 Ibid., pp. 53-54.

33 Because Royall Tyler was a resident of Boston and an ally of the Whig members of the town meeting, it is quite likely that the inner deliberations of the Council would become 
the records of the official deliberations of the Council - throws the Boston $\mathrm{Ga}$ zette account into a new light. The Boston Gazette's broadly accurate account omits the elements of the deliberations in the Council that were decisive in its change of heart: that the militia from the surrounding towns constituted a creditable threat of civil insurrection. In order to stay clear of the seditious tendency of such a threat, the Boston Gazette narrative foregrounds other features of the Town Meeting's performance: its restraint even when sorely provoked; its observation of its customary procedures (voting, appointing committees, and patiently awaiting results); the speed and decisiveness of its deliberations; the simplicity of its demand; and, most importantly, its achieved unity. By organising its account around authoritative public documents, the Boston Gazette's narrative has a 'cooling effect'. In response to the irregularity of the riot of 5 March, or the spectre of civil war that opened on 6 March, the Boston Gazette account represents the events of 6 March as a triumph of responsiblebecause disciplined - popular sovereignty. By this account, the passing of the crisis is due neither to Royal Officials, who prudently relent, nor to the Whig threat of civil insurrection. The concision of this narrative suggested the magical efficacy of the Town Meeting's disciplined moral resolve. The Town Meeting's exercise of self-government allows them to govern the action of others. By the way it acts, by the disciplined power it exercises, and by the lively 'spirit of liberty' it evidences, the Town Meeting emerges, in the account of the Boston Gazette, as the hero of 6 March.

If, as it is sometimes said, newspapers write the first draft of history, then this case history suggests that its history is partial and incomplete. The Boston Gazette's account of the day after the Boston massacre suggests the limits of the truth-value of even an accurate newspaper account. Paradoxically, its coverage is both factually correct but untrue. Because Whigs and Royal Officials have a divergent understanding of the reality that grounds the events under consideration, it is quite likely that Royal Officials and their Tory supporters found the Gazette's account to be accurate but essentially false. While both Whigs and Tories had no trouble agreeing upon certain details - names of the dead, time of the shooting, the fact that the ringing of bells gathered a crowd, etc. - these constitute only a thin layer of the realities in dispute. The Whig and Royal Officials diverge on essentials. There was no political consensus to decide whether what happened was a riot, a massacre, or an unfortunate

quickly known. It did not take long before Boston Whigs would have read Andrew Oliver's letter-affidavit in the ministry's pamphlet, A Fair Account of the Late Disturbances at Boston (London: 1770). See Hiller B. Zobel, The Boston Massacre (New York: W.W. Norton \& Co., 1970), pp. 212-213. 
accident, and exhaustive forensic analysis has never even settled who began the violence that ended in five deaths. The Whig's 'massacre' was labelled by Tories as an "unfortunate disturbance on King Street"; the Town Meeting's victory in compelling the removal of British troops was received in Whitehall as an alarming symptom of the "state of misgovernment in His Majesty's Province of Massachusetts". ${ }^{34}$ Whigs and Tories, drawing upon different parts of the news record, developed starkly divergent lessons with which to seed their mutual future. Each side published a polemical pamphlet to disseminate their version of events: the Tory pro-Ministerial pamphlet, written by John Mein, was published in London and entitled, A Fair Account of the Late Unhappy Disturbance at Boston in New England (see Figure 1.2). Then, to counter its influence, Boston Whigs published and sent to their supporters in London a rival pamphlet entitled, A Short Narrative of the Horrid Massacre in Boston Perpetrated on the Fifth Day of March 1770 (see Figure 1.3).

In the months after the events of $5^{-6}$ March 1770 , Boston Whigs and the British Ministry institutionalised the events in utterly different ways. The Whigs developed an annual oration to commemorate the massacre and celebrate the unity that had enabled them to triumph over the Royal Governor. These orations encouraged Boston Whigs to apply the republican moral lessons of 6 March - courage and firmness - to subsequent moments in the American Crisis. By contrast, the British Privy Council in Whitehall held a series of private meetings, patiently gathered evidence of the weakness of Royal government in Massachusetts, and then promulgated reforms of the Massachusetts provincial charter to strengthen government there. They included Royal appointment of previously elected councillors and sheriffs, as well as the requirement that all towns receive prior approval from the Governor for any non-routine town meeting. These plans were not implemented immediately, but when the Boston Whigs threw East India tea into Boston harbour at the end of 1773 , the Ministry took these plans off the shelf and introduced them into Parliament as the Massachusetts Government Act (1774). It was passed with unprecedented speed and became one of the triggers of revolution. By then, it had become evident that the peace so arduously achieved on 6 March was only temporary.

My brief discussion of the eighteenth-century newspaper suggests how, over time, newspapers became institutions that had established a reputation for truthfulness that readers could trust. Having modest expectations for their

34 'State of Disorders, Confusion, and Misgovernment which have lately prevailed and do still continue to prevail in His Majesty's province of the Massachusetts Bay in America', enclosed in John Pownall's letter to Clerk of Council, 21 June 1770, in Documents of the American Revolution, 1770-1783, pp. 110-128. 


\title{
$\begin{array}{lllllll}A & \mathbf{C} & \mathbf{C} & \mathrm{O} & \mathbf{U} & \mathbf{N} & \mathbf{T}\end{array}$
}

O F T H E I A T E

\section{Unhappy Difturbance}

\section{At Boston in New ENGLAND;}

\author{
EXTRACTED
}

From the DEPOSITIONS that have been made concerning it by Persons of all PARTIES.

\author{
W I T H A N \\ A P P E N D I X, \\ CONTAINING. \\ Some Affidavits and other Evidences relating to this \\ AFFAIR, not mentioned in the NARR A T IVE \\ of it that has been publined at BOSTON.
}

\section{O N D O N,}

Printed for B. WHI T E, in Fleet-ftreet. M DCC LXX.

FIGURE 1.2 Title-page of the Tory pro-Ministerial pamphlet A Fair Account of the Late Unhappy Disturbance at Boston in New England (1770).

newspapers, eighteenth-century readers saw them neither as heralds of liberty nor as sources of manipulative propaganda. Instead, they accepted newspapers as the most timely, varied, flexible source of information about events occurring in places remote from the paper's production. As such, they became 


\section{A S HOR T}

\section{N A R R A T I V E \\ OF THE}

\section{Horrid Maffacre in Bos ToN,}

PER PE T R A T E D

In the Evening of the Fifth Day of March $177^{\circ}$.

B $\mathbf{Y}$

SoLdrers of the XXIXth Regiment, which with the

XIVth Regiment were then quartered there:

W I T H S O M E

O

O N T H E

State of Things prior to that Catastrophe.

To which is added,

\section{A N A P P E N D I X,}

$\operatorname{con} t a+n+n$

The feveral Depofitions referred to in the preceding NAR\&ATIVE;

and alfo other Depofitions relative to the Subjed of it.

B O $\mathrm{S}$ T $\mathrm{O} \quad \mathrm{N}$,

Printed, by Order of the Toun, by Meffrs. EDEs and GiLl ;

$$
\text { A } \mathbf{N}
$$

Re-printed for W. B1sGLEY, in Newgate-Street, Losdox.

MDCSLXX.

FIGURE 1.3 Title-page of the Boston Whigs' pamphlet A Short Narrative of the Horrid Massacre in Boston Perpetrated on the Fifth Day of March 1770 (1770).

woven deep into the information ecology of the British Empire. But our look at the coverage of the day after the Boston 'massacre' also suggests that there never can be a definitive resolution of the opposition between fact and opinion; neither can there be a definitive answer to what might be the founding query directed at the early newspaper: is this news account accurate enough, inclusive enough, and unbiased enough to be considered true and trustworthy? 
The problematic of truth and error, trust and distrust, may render every answer to this question provisional and temporary. Thus, as the new American republic moved into the nineteenth century, the open, inclusive and impartial mode of eighteenth-century newspapers faded both as ideal and practice. Newspapers that served as agents of partisan opinion, party mobilisation, and democratic participation replaced them. ${ }^{35}$ Ever since readers of the newspaper have been obliged to dispute whether news is fair and balanced, trustworthy or true. Perhaps they always will.

35 In The Tyranny of Printers, Jeffrey Pasley argues that this development enabled partisan party papers - which framed the news by their political projects - to broaden participatory democratic politics in the early Republic. 